\title{
Temperature characteristics of bacterial sulfate reduction in continental shelf and slope sediments
}

\author{
J. E. Sawicka ${ }^{1,3}$, B. B. Jørgensen ${ }^{2}$, and V. Brüchert ${ }^{3}$ \\ ${ }^{1}$ Department of Biogeochemistry, Max Planck Institute for Marine Microbiology, Bremen, Germany \\ ${ }^{2}$ Center for Geomicrobiology, Department of Bioscience, Aarhus University, Aarhus, Denmark \\ ${ }^{3}$ Department of Geological Sciences, Stockholm University, Sweden
}

Correspondence to: J. E. Sawicka (joanna.sawicka@geo.su.se)

Received: 31 December 2011 - Published in Biogeosciences Discuss.: 18 January 2012

Revised: 13 July 2012 - Accepted: 14 July 2012 - Published: 30 August 2012

\begin{abstract}
The temperature responses of sulfate-reducing microbial communities were used as community temperature characteristics for their in situ temperature adaptation, their origin, and dispersal in the deep sea. Sediments were collected from a suite of coastal, continental shelf, and slope sediments from the southwest and southeast Atlantic and permanently cold Arctic fjords from water depths ranging from the intertidal zone to $4327 \mathrm{~m}$. In situ temperatures ranged from $8{ }^{\circ} \mathrm{C}$ on the shelf to $-1{ }^{\circ} \mathrm{C}$ in the Arctic. Temperature characteristics of the active sulfate-reducing community were determined in short-term incubations with ${ }^{35} \mathrm{~S}$-sulfate in a temperature gradient block spanning a temperature range from 0 to $40^{\circ} \mathrm{C}$. An optimum temperature $\left(T_{\text {opt }}\right)$ between $27^{\circ} \mathrm{C}$ and $30^{\circ} \mathrm{C}$ for the South Atlantic shelf sediments and for the intertidal flat sediment from Svalbard was indicative of a psychrotolerant/mesophilic sulfate-reducing community, whereas $T_{\mathrm{opt}} \leq 20^{\circ} \mathrm{C}$ in South Atlantic slope and Arctic shelf sediments suggested a predominantly psychrophilic community. High sulfate reduction rates $(20-50 \%)$ at in situ temperatures compared to those at $T_{\mathrm{opt}}$ further support this interpretation and point to the importance of the ambient temperature regime for regulating the short-term temperature response of sulfate-reducing communities. A number of cold $\left(<4{ }^{\circ} \mathrm{C}\right)$ continental slope sediments showed broad temperature optima reaching as high as $30^{\circ} \mathrm{C}$, suggesting the additional presence of apparently mesophilic sulfate-reducing bacteria. Since the temperature characteristics of these mesophiles do not fit with the permanently cold deep-sea environment, we suggest that these mesophilic microorganisms are of allochthonous origin and transported to this site. It is likely that they were deposited along with the mass-flow move-
\end{abstract}

ment of warmer shelf-derived sediment. These data therefore suggest that temperature response profiles of bacterial carbon mineralization processes can be used as community temperature characteristics, and that mixing of bacterial communities originating from diverse locations carrying different temperature characteristics needs to be taken into account to explain temperature response profiles of bacterial carbon mineralization processes in sediments.

\section{Introduction}

About $95 \%$ of the seafloor is permanently cold with in situ temperatures below $4{ }^{\circ} \mathrm{C}$ (Levitus and Boyer, 1994). Bacteria carrying out carbon mineralization in the cold seabed must be adapted to operate effectively under such low temperatures. Hence, psychrophilic bacteria with suitable cell membrane fluidity and cold-adapted enzymes are particularly abundant in the deep sea (Margesin and Miteva, 2011). As a result of such microbial adaptation to low temperature, the rate and efficiency of organic carbon mineralization in the cold may be as high as in temperate and warm habitats (Kostka et al., 1999). However, bacteria that grow at temperatures extending into the mesophilic range and that do not show cold adaptations were also isolated from the cold deep seafloor (Rüger, 1989; Rüger and Tan, 1992; Finster and Bak, 1993; Chen et al., 2003; Aono et al., 2010).

Thermal adaptation and flexibility of microorganisms to function effectively in different temperature regimes is related to underlying molecular mechanisms, e.g. to the presence of a large number of genes induced at low 
temperatures and cold-adapted proteins (Ting et al., 2011; Casanueva et al., 2010). Phenotypically these molecular adaptations are expressed as different cardinal temperatures of growth or respiration, i.e. a temperature minimum $\left(T_{\min }\right)$, maximum ( $\left.T_{\max }\right)$ and optimum ( $\left.T_{\mathrm{opt}}\right)$, the $T_{\mathrm{opt}}$ indicating the temperature of the highest rate. By definition, psychrophilic bacteria have a temperature minimum $<0^{\circ} \mathrm{C}$, optimum $\leq$ $15^{\circ} \mathrm{C}$, and maximum $\leq 20^{\circ} \mathrm{C}$. Psychrotolerant bacteria have a minimum $\leq 0^{\circ} \mathrm{C}$, optimum $\leq 25^{\circ} \mathrm{C}$, and maximum $\leq$ $35^{\circ} \mathrm{C}$. Mesophilic bacteria have a minimum $>0{ }^{\circ} \mathrm{C}$, optimum $25-40^{\circ} \mathrm{C}$, and maximum $35-40^{\circ} \mathrm{C}$ (Morita, 1975).

Bacterial sulfate reduction is the predominant anaerobic carbon mineralization pathway in most continental shelf and slope sediments (Kasten and Jørgensen, 2006) and is also detected in sediments of the continental rise and the abyssal plains (Ferdelman et al., 1999; D'Hondt et al., 2002; Lee et al., 2008). Sulfate reduction rates can be quantified with high sensitivity and precision by incubating sediment with ${ }^{35} \mathrm{~S}$ sulfate and measuring the rate of ${ }^{35} \mathrm{~S}$-sulfide formation (Fossing, 1995; Kallmeyer et al., 2004). This technique is one of the few that link the quantification of organic carbon mineralization rates to a physiologically defined group of microorganisms (Leloup et al., 2007; Lee et al., 2008).

Incubation of sediments or of pure cultures in a temperature gradient has been used to determine the cardinal temperatures for growth or respiration of microbial communities (Battley, 1964). Temperature-activity curves possess multiple properties that define the temperature characteristics of a community. Rates of metabolism at in situ temperatures relative to the rates at $T_{\mathrm{opt}}$ indicate how well bacteria perform under ambient low temperatures (Knoblauch and Jørgensen, 1999). The Arrhenius plot can be used for a graphical representation of the temperature dependence of bacterial metabolism (Arrhenius, 1908). Thereby, the logarithm of the rate of bacterial respiration or growth versus the inverse absolute temperature yields a linear relationship in the temperature range where the bacteria are well adapted, whereas deviation from a linear slope at the upper or lower extreme expresses the inability of Sulfate Reducing Bacteria (SRB) to maintain a well-controlled metabolic activity and may indicate decoupled electron flow from Adenosine5'-triphosphate (ATP) formation. The slope of the correlation can be used to calculate the apparent activation energy, $E_{\mathrm{a}}$, where the $E_{\mathrm{a}}$ can be defined as the minimum energy required for initiating a chemical reaction. A reduction of the $E_{\mathrm{a}}$ value may therefore result in an increase of the reaction rate. Apparent $E_{\mathrm{a}}$ values are not activation energies in the strict chemical sense, because sulfate reduction occurs through a series of enzymatic reactions. Calculated $E_{\mathrm{a}}$ values therefore measure an ecological response of the whole SRB community to temperature changes rather than the cooperative process between structural elements of an enzyme or a rate-limiting chemical step. From the energy of activation in a given temperature interval the $Q_{10}$ value is calculated, i.e. the factor by which the rate of a reaction increases at a temperature increase of $10^{\circ} \mathrm{C}$ (Arrhenius, 1908).

Such incubations have shown that temperate sediments and permanently cold Arctic or Antarctic sediments host bacteria with widely different temperature adaptations (Isaksen and Jørgensen, 1996; Knoblauch and Jørgensen, 1999; Sahm et al., 1999; Brüchert et al., 2001; Hubert et al., 2009).

In the present study we analyze the temperature dependence of sulfate reduction in shelf and slope sediments from the southwest and southeast Atlantic and compare these data to permanently cold shelf sediments off Svalbard in the Arctic Ocean.

We want to assess to which extent the temperature response of the microbial communities reflects the ambient temperature. We attempt to explain the observed temperature characteristics and the cardinal temperatures of existing communities by adaptation mechanisms and mixing of different temperature groups of microorganisms.

\section{Material and methods}

Sediments from the South Atlantic were collected in 2008 and 2009 at six stations located on the shelf and slope off central Namibia and off Uruguay and Argentina, respectively. Sediments from four stations in the Arctic were collected in 1998, 1999 and 2007 from fjords and an intertidal flat on the west coast of Svalbard. Samples were taken from the sediment zone of highest sulfate reduction rates, which was typically in the depth range of 3-10 cm. Sediments were stored in gas-tight plastic bags at $4{ }^{\circ} \mathrm{C}$ until further processing in the laboratory within a few days. For measurements of rates in intact sediment cores, cores of $26 \mathrm{~mm}$ diameter and ca. $15 \mathrm{~cm}$ length were taken, sealed at both ends with rubber stoppers leaving air in the headspace, and stored at $4{ }^{\circ} \mathrm{C}$. Coordinates for the study sites, in situ temperatures, and water depths at which sediments were collected are given in Table 1.

\subsection{Oceanography and sedimentary setting}

\subsubsection{Namibian shelf and slope}

The Benguela upwelling system has extremely high primary productivity of $767-1051 \mathrm{~g} \mathrm{C} \mathrm{m}^{-2} \mathrm{yr}^{-1}$ and is the most productive coastal upwelling area on Earth (Carr, 2002). The bottom water temperatures of the Namibian shelf vary annually between 7 and $10^{\circ} \mathrm{C}$ on the shelf and between 1 and $4^{\circ} \mathrm{C}$ on the slope (Lass and Mohrholz, 2005). The shelf and slope system is characterized by seaward and downslope particle transport that maintains local high sedimentation rates in a depocenter at 1000-1500 m water depth (Inthorn et al., 2005). Sediments were collected from two stations during the RV Meteor cruise M76/1 (Zabel and Ferdelman, 2008), one on the shelf in $130 \mathrm{~m}$ water depth and one on the continental slope in $2000 \mathrm{~m}$ water depth. Sediments from the shelf and from the slope have high concentrations of organic carbon 
Table 1. Sampling sites description.

\begin{tabular}{lrrr}
\hline Station & Coordinates & Water depth $(\mathrm{m})$ & in situ $T^{\circ} \mathrm{C}$ \\
\hline (1) Namibian shelf & $25^{\circ} 0^{\prime} \mathrm{S}, 14^{\circ} 23^{\prime} \mathrm{E}$ & 130 & 8 \\
(2) Uruguay shelf & $36^{\circ} 08^{\prime} \mathrm{S}, 53^{\circ} 16^{\prime} \mathrm{W}$ & 244 & 8 \\
(3) Namibian slope & $25^{\circ} 45^{\prime} \mathrm{S}, 13^{\circ} 3^{\prime} \mathrm{E}$ & 2000 & 2 \\
(4) Argentine Basin & $38^{\circ} 12^{\prime} \mathrm{S}, 54^{\circ} 56^{\prime} \mathrm{W}$ & 627 & 4 \\
(5) Argentine Basin & $37^{\circ} 57^{\prime} \mathrm{S}, 53^{\circ} 50^{\prime} \mathrm{W}$ & 3400 & 2 \\
(6) Argentine Basin & $39^{\circ} 28^{\prime} \mathrm{S}, 53^{\circ} 42^{\prime} \mathrm{W}$ & 4327 & 1 \\
(7) Arctic intertidal flat & $78^{\circ} 16^{\prime} \mathrm{N}, 14^{\circ} 02^{\prime} \mathrm{E}$ & 0 & 6 \\
(8) Krossfjord & $79^{\circ} 08^{\prime} \mathrm{N}, 11^{\circ} 39^{\prime} \mathrm{E}$ & 80 & 0 \\
(9) Kongsfjord & $79^{\circ} 00^{\prime} \mathrm{N}, 11^{\circ} 40^{\prime} \mathrm{E}$ & 110 & -1 \\
(10) Smeerenburgfjord & $79^{\circ} 42^{\prime} \mathrm{N}, 11^{\circ} 05^{\prime} \mathrm{E}$ & 215 & 2 \\
\hline
\end{tabular}

of up to $20 \%$ dry weight that decrease to about $7-8 \%$ in the depocenter on the continental slope (Inthorn et al., 2005). This decrease corresponds well with the decrease in sulfate reduction rates (SRR) with increasing water depth (Table 2, Brüchert et al., 2003).

\subsubsection{SW Atlantic margin and basin}

The region off Uruguay and Argentina has dynamic oceanographic conditions due to the confluence of two different water masses that causes high primary productivity and high deposition of organic matter (e.g. Behrenfeld and Falkowski, 1997). Sediments from the SW Atlantic were collected during RV Meteor cruise M78/3 on the continental shelf off Uruguay and on the slope off Argentina (Krastel and Wefer, 2009). Shelf bottom water temperatures vary between 7 and $10^{\circ} \mathrm{C}$, and continental slope bottom water temperatures are between 1 and $4{ }^{\circ} \mathrm{C}$ (Hansen et al., 2003; Ortega and Martinez 2007). This region is characterized by high sedimentation rates, gravity mass flows due to major turbidities and slides, and strong surface currents (Riedinger et al., 2005). The sediments in the study area are characterized by low carbonate concentrations and high concentrations of organic carbon and iron oxides (Hansen et al., 2003). SRR and total organic carbon (TOC) contents are of the same magnitude as in shelf sediments off Namibia (Table 2). The TOC contents of Argentine slope sediments decrease with water depth from about $5 \%$ to $1 \%$ dry weight.

\subsubsection{West coast of Svalbard}

Along the west coast of Svalbard, primary productivity is controlled by light availability, ice cover, and the influence of the West Spitsbergen current, which transports relatively warm water $\left(0.5\right.$ to $\left.2{ }^{\circ} \mathrm{C}\right)$ from the North Atlantic to this latitude (Carmack et al., 2006). These Arctic sediments have very constant temperatures throughout the year, ranging from $-1{ }^{\circ} \mathrm{C}$ to $+2{ }^{\circ} \mathrm{C}$. Intertidal mud flats on the west coast of Svalbard have summer temperatures as high as $6^{\circ} \mathrm{C}$, but drop to $-20^{\circ} \mathrm{C}$ during the winter (Nordli, 2005). The mean annual primary production along the west coast is around $120 \mathrm{~g} \mathrm{C} \mathrm{m}^{-2} \mathrm{yr}^{-1}$ (Sakshaug, 2004). SRR are also relatively high and comparable to rates of many temperate shelf areas (Sagemann et al., 1998). Sediment was collected from four stations along the west coast of the main island of the Svalbard archipelago, Spitsbergen. Three stations were located centrally in fjords while the fourth was on an intertidal mud flat. The fjord sediments were taken in July 1998 and July 1999 with a Haps corer while the intertidal flat was sampled in August 2008 from the shore.

\subsection{Sulfate reduction rate measurements}

Sulfate reduction rates (SRR) were measured in two parallel sediment cores using the whole core incubation method by Jørgensen (1978). These data are henceforth termed in situ SRR. $5 \mu$ l of carrier-free ${ }^{35} \mathrm{SO}_{4}^{2-}$ tracer solution in $4 \%$ $\mathrm{NaCl}$ ( $\sim 100 \mathrm{kBq}$ per injection) was injected at $1 \mathrm{~cm}$ intervals to a depth of $16 \mathrm{~cm}$. Incubation time was $8 \mathrm{~h}$ at the in situ temperature. Samples that were collected in 1998 and 1999 were distilled by the hot chromium reduction method described by Fossing and Jørgensen (1989). Samples collected in 2008 and 2009 were analyzed using the low-blank cold chromium distillation method described by Kallmeyer et al. (2004). Briefly, centrifuged sediment was diluted with $10 \mathrm{ml}$ dimethylformamide and placed in a distillation flask. Total reduced inorganic sulfide (TRIS) was acid-distilled under nitrogen at room temperature after adding $12 \mathrm{ml}$ 6N HCL and $12 \mathrm{ml} 1 \mathrm{M}$ chromium chloride. The TRIS was recovered as zinc sulfide in traps containing $7 \mathrm{ml}$ of $5 \% \mathrm{w} / \mathrm{v}$ zinc acetate solution and ${ }^{35} \mathrm{~S}$ was counted in a liquid scintillation counter (Packard, Tricarb 2500 TR). The scintillation cocktail was Lumasafe Plus (Lumac BV, Groningen, The Netherlands) mixed in a ratio of $2: 1(\mathrm{v} / \mathrm{v})$ with the $\mathrm{ZnS}$ suspension.

\subsection{Temperature dependence of SRR}

The temperature dependence of SRR was determined in temperature gradient incubation experiments using a thermostated aluminum block (Isaksen and Jorgensen, 1996). 
Table 2. Bulk geochemical analysis. Carbon and nitrogen concentrations determined for Namibian, Uruguayan, Argentine and Arctic sediments.

\begin{tabular}{lrrrr}
\hline Station & $\begin{array}{r}\text { Organic } \\
\text { carbon }(\text { wt } \%)\end{array}$ & $\begin{array}{r}\text { Nitrogen } \\
(\text { wt \%) }\end{array}$ & C/N & $\begin{array}{r}\text { SRR nmol cm } \\
\text { (SR zone mean })\end{array}$ \\
\hline Namibia $130 \mathrm{~m}$ & 4.4 & 0.5 & 10.5 & 65.8 \\
Namibia $2000 \mathrm{~m}$ & 6.5 & 0.9 & 10.4 & 3.59 \\
Uruguay $244 \mathrm{~m}$ & 5.0 & 0.6 & 10.0 & 43.6 \\
Argentina $627 \mathrm{~m}$ & 2.3 & 0.3 & 10.3 & nd \\
Argentina $3400 \mathrm{~m}$ & 1.3 & 0.2 & 9 & nd \\
Argentina $4327 \mathrm{~m}$ & $\mathrm{nd}$ & $\mathrm{nd}$ & $\mathrm{nd}$ & 6 \\
Arctic 0 m & 1.4 & 0.1 & 16 & 11 \\
Krossfjord $80 \mathrm{~m}$ & $\mathrm{nd}$ & $\mathrm{nd}$ & $\mathrm{nd}$ & 4.29 \\
Kongsfjord $110 \mathrm{~m}$ & $\mathrm{nd}$ & $\mathrm{nd}$ & $\mathrm{nd}$ & 12.6 \\
Smeerenburgfjord $215 \mathrm{~m}$ & 1.2 & 0.2 & 8.8 & 19.4 \\
\hline
\end{tabular}

The temperature in the gradient block ranged from $-5^{\circ} \mathrm{C}$ to $+40{ }^{\circ} \mathrm{C}$ with a temperature increment between each sample of $1.5^{\circ} \mathrm{C}$. On an absolute temperature scale, this temperature difference is small with regard to the temperature dependence of enzymatic responses. We do not provide a standard error for each measurement, but the degree of scatter of neighboring data points indicates the precision of the method and serves as an estimation of the analytical uncertainty and sample variability. The interpolated trend for each temperature response experiment is thus statistically substantiated as the temperature trend integrates the analytical uncertainty. Hence, the sediments were not incubated in replicates, with the exception of the Argentine sediment from the $3400 \mathrm{~m}$ depth. Sediment slurries were prepared by 1:2(w/v) dilution with anoxic artificial seawater (Widdel and Bak, 1992). Sediment slurries were made anoxic by bubbling with $\mathrm{N}_{2}$, and $5 \mathrm{ml}$ of slurry was transferred to each Hungate tube. Hungate tubes were flushed with $\mathrm{N}_{2}$ (Bryant, 1972) and sealed with butyl rubber stoppers. The Hungate tubes were immediately placed in the temperature gradient block and pre-incubated to allow the sediments to reach thermal equilibrium. Then ${ }^{35}$ S-labeled carrier-free sulfate $(100 \mathrm{kBq}$ final activity) was injected and the slurries were incubated with radiotracer. The South Atlantic sediments were pre-incubated for $12 \mathrm{~h}$, and subsequently incubated with ${ }^{35}$ S-labeled sulfate for 24 hours. The sediments from the three Arctic fjords (Kongsfjorden, Krossfjorden, and Smeerenburgfjorden) were pre-incubated for one hour, and then incubated for $12 \mathrm{~h}$ with ${ }^{35} \mathrm{~S}$-labeled sulfate for Kongsfjorden and Krossfjorden sediment, and 8 hours for Smeerenburgfjorden sediment. Incubations were stopped by transferring the sediment to $50 \mathrm{ml}$ polyethylene centrifuge tubes with $20 \mathrm{ml} 20 \%$ zinc acetate to stop bacterial activity and to fix sulfides. Samples were kept frozen until further analysis. Subsequent distillation followed procedures described in Kallmeyer et al. (2004) for samples collected in 2008 and 2009 and in Fossing and Jørgensen (1989) for samples collected in 1998 and 1999.

\subsection{Arrhenius plot and $Q_{10}$}

Activation energies were calculated from the linear range of data in an Arrhenius-type diagram where the ${ }^{35} \mathrm{~S}$-sulfate reduction rate, $k$, is plotted as a function of the inverse temperature $(1 / T)$ :

$\ln (k)=\ln (A)+\left(\frac{-E_{\mathrm{a}}}{R} \cdot \frac{1}{T}\right)$

where $E_{\mathrm{a}}$ is the activation energy $\left(\mathrm{J} \mathrm{mol}^{-1}\right), k$ is the rate of sulfate reduction $\left(\mathrm{nmol} \mathrm{cm}{ }^{-3} \mathrm{day}^{-1}\right) . A$ is a constant, $R$ is the molecular gas constant $\left(8.314 \mathrm{~J} \mathrm{~K}^{-1} \mathrm{~mol}^{-1}\right)$, and $T$ is the absolute temperature $(\mathrm{K})$.

$Q_{10}$ values between $0{ }^{\circ} \mathrm{C}$ and $10^{\circ} \mathrm{C}$ were calculated according to:

$Q_{10}=\exp \left[\frac{E_{\mathrm{a}} \cdot 10}{R T(T+10)}\right]$.

\subsection{Solid phase analyses}

Freeze-dried and homogenized sediment was analyzed for total carbon (TC) and total nitrogen (TN) with a Fisons NA 1500 Series 2 Elemental Analyzer. Total inorganic carbon (TIC) was measured with a CM 5240 Orbis BV coulometer. Total organic carbon (TOC) was calculated by subtracting TIC from TC.

\subsection{Sulfate measurements}

Porewater sulfate concentrations were determined after centrifugation of sediment at $3500 \mathrm{rpm}$ in capped centrifuge tubes with nitrogen headspace at $4{ }^{\circ} \mathrm{C}$ for $15 \mathrm{~min}$. Supernatant pore water $(1 \mathrm{ml})$ was preserved with $200 \mu 11 \%(\mathrm{w} / \mathrm{v})$ $\mathrm{Zn}$-acetate solution and stored frozen at $-20^{\circ} \mathrm{C}$. Sulfate concentrations were measured by suppressed ion chromatography after 1:100 dilution with deionized water on a Metrohm 761 compact ion chromatograph. Sulfate standards were prepared from $\mathrm{Na}_{2} \mathrm{SO}_{4}$, with concentrations ranging from 5 to 
$400 \mu \mathrm{M}$ using an eight-point calibration curve. Quality control samples, treated as unknowns, were prepared from calibrated seawater (IAPSO) and analyzed at the start and end of every sample run sequence.

\section{Results}

\subsection{Characterization of study sites}

The organic carbon and nitrogen content, expressed as \% dry weight, and the molar C:N ratio are listed in Table 2. The highest organic carbon content was measured in Namibian (4.4\% TOC) and Uruguayan (5.0\% TOC) shelf sediments, and Namibian (6.5\% TOC) slope sediment. In the other sediments, TOC ranged from $1.2 \%$ to $2.3 \%$ TOC. The total nitrogen $(\mathrm{TN})$ concentration ranged from $0.1 \%$ to $0.9 \%$. Except for the Arctic intertidal flat sediments, where the molar $\mathrm{C}: \mathrm{N}$ ratio was 16, C:N ratios calculated for other sediments ranged between 8 and 10. C:N ratios near 10 determined for South Atlantic sediments are typical for sediments with high TOC content deposited under highly productive marine systems with associated high organic matter fluxes (Meyers, 1994). C:N ratios of $<10$ generally characterize labile organic matter easily accessible to microorganisms.

Average rates of in situ SRR in the zone of highest sulfate reduction (top 3 to $9 \mathrm{~cm}$ ) are presented in Table 2. Highest rates were found in the Namibian shelf sediment, $65.8 \mathrm{nmol} \mathrm{cm}^{-3} \mathrm{~d}^{-1}$, and Uruguayan shelf sediment, $43.6 \mathrm{nmol} \mathrm{cm}{ }^{-3} \mathrm{~d}^{-1}$. The lowest SRR was found in Argentinian sediment from $3400 \mathrm{~m}$ water depth, $6 \mathrm{nmol} \mathrm{cm}^{-3} \mathrm{~d}^{-1}$, in the Arctic fjord sediment from Krossfjorden, $4.29 \mathrm{nmol}$ $\mathrm{cm}^{-3} \mathrm{~d}^{-1}$, and in Namibian slope sediment from $2000 \mathrm{~m}$ water depth, $3.59 \mathrm{nmol} \mathrm{cm}^{-3} \mathrm{~d}^{-1}$.

\subsection{Temperature dependence of SRR, South Atlantic}

The SRR measured in slurried sediments in the temperature gradient block are not representative of in situ rates, yet they are clearly related to ambient temperatures, water depth, and the availability of organic matter. In situ temperatures of Namibian and Uruguayan shelf sediments define a temperate environment conducive for mesophilic to psychrotolerant microorganisms. This is supported by the temperature curves of sulfate reduction in the shelf sediments (Fig. 1a, b), and the three cardinal temperatures, $T_{\min }, T_{\mathrm{opt}}$, and $T_{\max }$ (Table 3 ). In both shelf sediments $T_{\text {opt }}$ was between 25 and $30^{\circ} \mathrm{C}$. SRR in Namibian slope sediments were $7 \mathrm{nmol} \mathrm{cm}^{-3} \mathrm{~d}^{-1}$ at the in situ temperature and increased to $72 \mathrm{nmol} \mathrm{cm}^{-3} \mathrm{~d}^{-1}$ at $T_{\text {opt. }}$ In the Uruguayan sediment SRR were $3 \mathrm{nmol} \mathrm{cm}^{-3} \mathrm{~d}^{1}$ at the in situ temperature and increased to $16 \mathrm{nmol} \mathrm{cm}^{-3} \mathrm{~d}^{-1}$ at the $T_{\text {opt }}$.

In situ temperatures in the Namibian and Argentinian slope sediments range annually between $1{ }^{\circ} \mathrm{C}$ and $4{ }^{\circ} \mathrm{C}$ (Siedler, 1996). In these sediments the $T_{\text {opt }}$ of sulfate reduction was distinctly lower than in the corresponding shelf
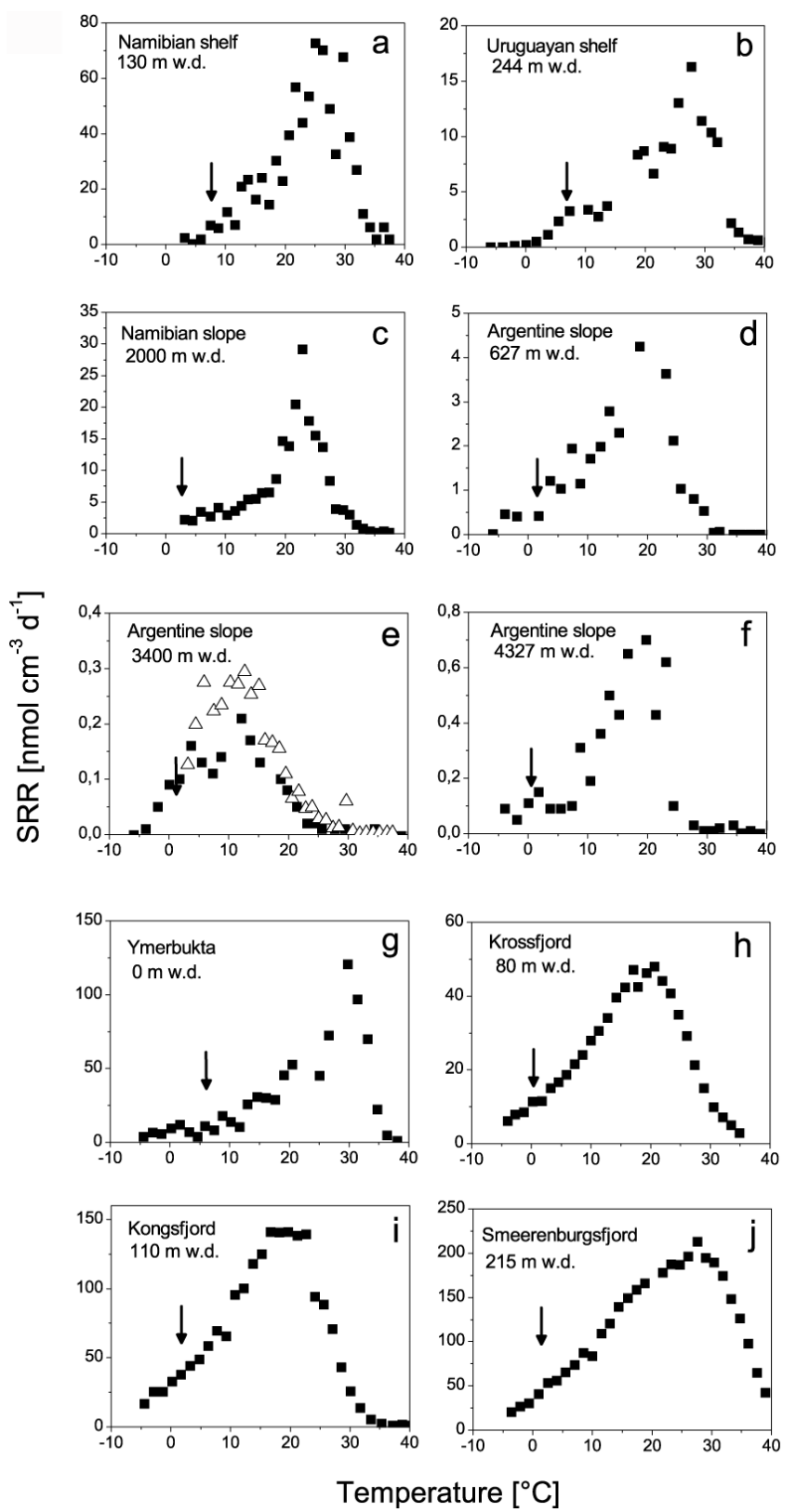

Fig. 1. SRR measured in temperature-gradient incubation experiments of sediment slurries from the different sampling sites. Arrows indicate in situ temperatures of sediments, w.d. stands for water depth. Argentine Basin sediment from the depth $3400 \mathrm{~m}$ was incubated twice and a duplicate curve was added to the panel (e).

sediments. The highest SRR were found at $22^{\circ} \mathrm{C}$ and $20^{\circ} \mathrm{C}$ (Fig. 1c, d, f), and the $T_{\max }$ was near $30^{\circ} \mathrm{C}$. A $T_{\text {opt }}$ of only $12^{\circ} \mathrm{C}$ was found in one of the sediments from the Argentinian slope in $3400 \mathrm{~m}$ water depth (Fig. 1e). This sediment showed a broad temperature profile between $0^{\circ} \mathrm{C}$ and $15^{\circ} \mathrm{C}$, but above $20^{\circ} \mathrm{C}$ SRR dropped below the detection limit. 
Table 3. Sulfate reduction activities and Arrhenius parameters determined in the temperature-gradient incubation experiments for Namibian, Uruguayan, Argentine and Arctic sediments.

\begin{tabular}{|c|c|c|c|c|c|c|}
\hline \multirow{2}{*}{ Station } & \multirow{2}{*}{$T_{\text {opt }}\left({ }^{\circ} \mathrm{C}\right)$} & \multicolumn{2}{|c|}{ SRR $\mathrm{nmol} \mathrm{cm}^{-1} \mathrm{~d}^{-1}$} & \multirow[t]{2}{*}{$\%$ SRR } & \multirow[t]{2}{*}{$E_{\mathrm{a}} \mathrm{kJ} \mathrm{mol}^{-1}$} & \multirow[t]{2}{*}{$Q_{10}$} \\
\hline & & at in situ $T$ & at $T_{\mathrm{opt}}$ & & & \\
\hline Namibia $130 \mathrm{~m}$ & 25 & 7 & 72 & 9 & 55 & 2.8 \\
\hline Namibia $2000 \mathrm{~m}$ & 22 & 2 & 29 & 7 & 38 & 2 \\
\hline Uruguay 244 m & 27 & 3 & 16 & 20 & 32 & 2.9 \\
\hline Argentina $627 \mathrm{~m}$ & 20 & 0.15 & 0.7 & 21 & 30 & 2.8 \\
\hline Argentina $3400 \mathrm{~m}$ & 12 & 0.1 & 0.2 & 50 & 52 & 2.7 \\
\hline Argentina $4327 \mathrm{~m}$ & 20 & 1.2 & 4.3 & 28 & 26 & 2.7 \\
\hline Arctic $0 \mathrm{~m}$ & 30 & 8 & 120 & 15 & 25 & 2.7 \\
\hline Krossfjord $80 \mathrm{~m}$ & 25 & 9.1 & 44 & 20 & 27 & 2.3 \\
\hline Kongsfjord $110 \mathrm{~m}$ & 18 & 27 & 141 & 19 & 31 & 2.1 \\
\hline Smeerenburgfjord $215 \mathrm{~m}$ & 27 & 41 & 213 & 19 & 25 & 2 \\
\hline
\end{tabular}

\subsection{Temperature dependence of SRR, Arctic}

In the Arctic fjord sediments, the highest rates were measured in Smeerenburgfjorden (Fig. 1j). In this fjord, the SRR were $53 \mathrm{nmol} \mathrm{cm} \mathrm{cm}^{-3} \mathrm{~d}^{-1}$ at the in situ temperature and increased to $200 \mathrm{nmol} \mathrm{cm}{ }^{-3} \mathrm{~d}^{-1}$ at the $T_{\text {opt }}$. In the Arctic intertidal mud flat (Ymerbukta) and in Kongsfjorden sediment, SRR were about $40 \%$ lower than at the $T_{\text {opt }}$ (Fig. 1g, i). In Ymerbukta sediment, rates increased from 4 at $-4{ }^{\circ} \mathrm{C}$ to 120 nmol cm${ }^{-3} \mathrm{~d}^{-1}$ at $T_{\text {opt }}$, and in Kongsfjorden sediment, they increased from 27 at $-4{ }^{\circ} \mathrm{C}$ to $141 \mathrm{nmol} \mathrm{cm}{ }^{-3} \mathrm{~d}^{-1}$ at the $T_{\text {opt }}$. In the other Arctic fjord sediments, rates increased from 4 to $44 \mathrm{nmol} \mathrm{cm}{ }^{-3} \mathrm{~d}^{-1}$ at $T_{\text {opt }}$ (Fig. 1h).

The temperature profile of SRR in Ymerbukta increased in the temperature range from $-4{ }^{\circ} \mathrm{C}$ to $30^{\circ} \mathrm{C}$ and dropped to near the detection limit at a $T_{\max }$ of $35^{\circ} \mathrm{C}$ (Fig. 1g). In Smeerenburgfjorden and Krossfjorden sediment, the temperature response curve was broad and increased from $-4^{\circ} \mathrm{C}$ to $27^{\circ} \mathrm{C}$ and $23^{\circ} \mathrm{C}$ with a $T_{\max }$ at 40 and $34^{\circ} \mathrm{C}$, respectively (Fig. 1g, h). Likewise, in Kongsfjorden sediment, SRR showed a psychrotolerant response as activity increased from $-4^{\circ} \mathrm{C}$ to a maximum at $18^{\circ} \mathrm{C}$, but was barely detectable above $34^{\circ} \mathrm{C}$.

\subsection{Arrhenius plots and $Q_{10}$}

For all stations the relative metabolic rates at in situ temperatures (compared to those at $T_{\text {opt }}$ ) ranged between $9 \%$ and $50 \%$ (Table 3, Fig. 2). Activation energies calculated from the Arrhenius plots ranged from 25 to $55 \mathrm{~kJ} \mathrm{~mol}^{-1}$ while the $Q_{10}$ factors were in the range of 2 to 3 (Table 3). In Namibian sediments activation energies ranged from 33 to $55 \mathrm{~kJ} \mathrm{~mol}^{-1}$ and in Argentine sediments from 26 to $55 \mathrm{~kJ} \mathrm{~mol}^{-1}$.

\section{Discussion}

\subsection{Temperature response of SRR depends on in situ $T^{\circ} \mathrm{C}$ and on water depth}

The most important property of temperature-SRR curves is the relative rate at in situ temperature in relation to the rate at $T_{\text {opt }}$ (Knoblauch and Jørgensen, 1999). High rates at in situ temperature reflect a better adaptation of a process to the ambient temperature. The $T_{\mathrm{opt}}$ is an additional characteristic of a metabolic process that is dependent on the ambient temperature. In permanently cold sediments the $T_{\mathrm{opt}}$ of respiration and growth is always higher than the environmental temperatures the microorganisms experience (Feller, 2007). Therefore, the $T_{\text {opt }}$ itself is not a good indicator of a community's adaptation to temperature, because the $T_{\mathrm{opt}}$ more reflects the threshold temperature above which enzymatic functions rapidly degrade.

Our results support the basic notion that the ambient temperature regime of marine environments selects for microbial populations with the best physiology for the respective environment. The permanently cold fjord sediments of the Arctic thus appear to host predominantly psychrophilic to psychrotolerant populations while the SRR-temperature profile in temperate sediments reflects more mesophilic populations (cf. Isaksen et al., 1994; Sagemann et al., 1998; Isaksen and Jørgensen, 1996).

In the three Arctic deep-fjord sediments with bottom water temperatures permanently near $0{ }^{\circ} \mathrm{C}$, temperature selected for well-adapted SRB communities, because the relative respiration rates at in situ temperatures were high compared to the rates at $T_{\mathrm{opt}}$. The Arctic intertidal flat sediment of Ymerbukta on Svalbard has seasonal temperature fluctuations between $-20^{\circ} \mathrm{C}$ and $+9^{\circ} \mathrm{C}$, which should favor a community with mixed temperature characteristics. This interpretation is in accordance with the lower relative respiration rates at in situ temperatures and the higher $T_{\mathrm{opt}}$ than in the three Arctic permanently cold deep-fjord sediments. Likewise, the 


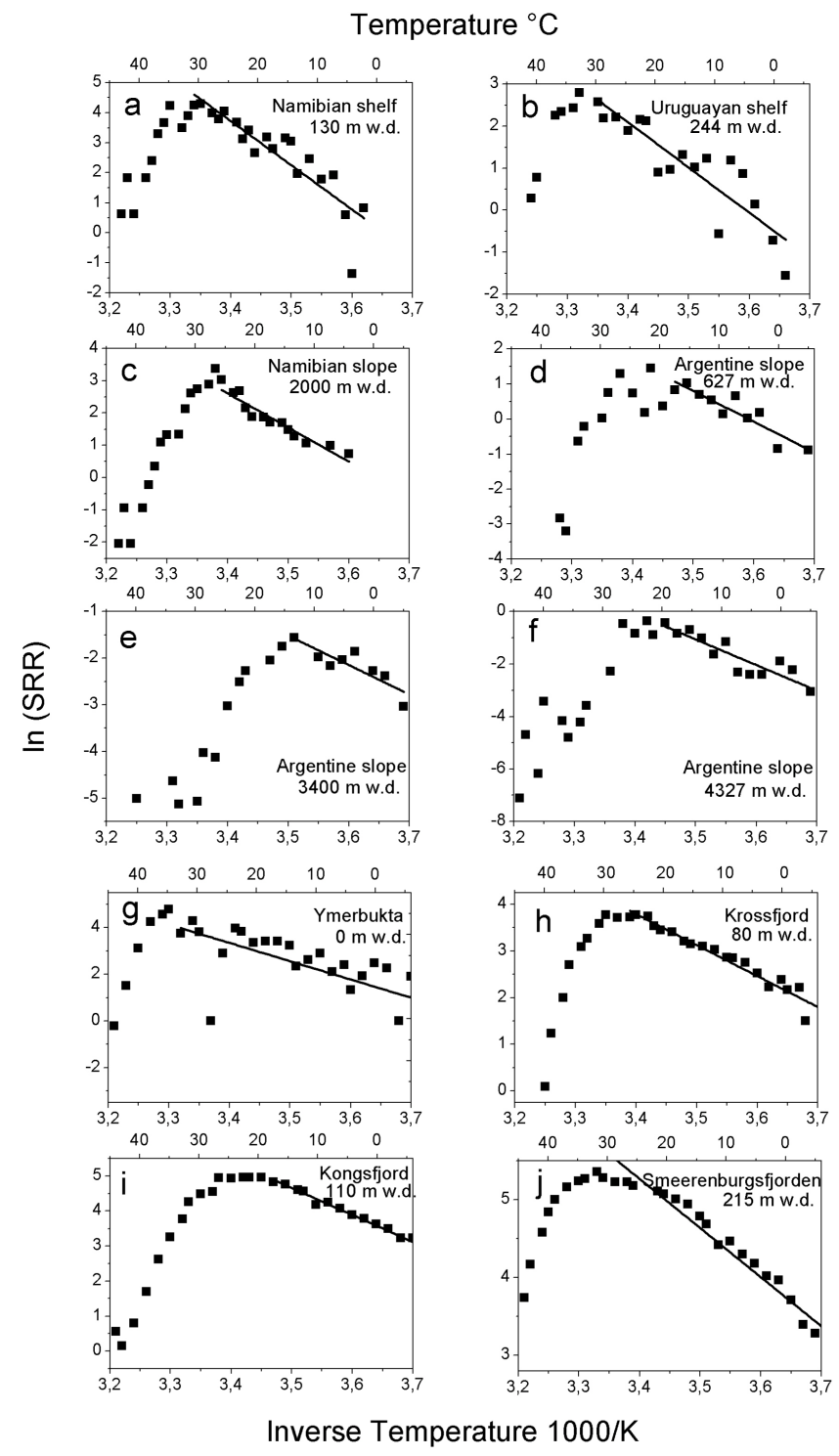

Fig. 2. Arrhenius plots of data in Fig. 1.

relatively warm bottom water temperatures of the Uruguayan and Namibian shelf of $7-10^{\circ} \mathrm{C}$ are consistent with relatively high $T_{\text {opt }}$ of 25 to $30^{\circ} \mathrm{C}$ and therefore suggest a greater abundance of mesophilic populations in these sediments (Fig. 1a, $b, j)$.

In the South Atlantic sediments, the $T_{\mathrm{opt}}$ and $T_{\max }$ of sulfate reduction also decreased along with the decrease in in situ temperature at greater water depths (Fig. 1b, c, d, f), but the temperature characteristics differed between the slope sediments. The most extreme demonstration of the temperature selection for an adapted microbial community that is reflected by all properties of the temperature-SRR curve is seen in the Argentine sediment from $3400 \mathrm{~m}$ depth, where we measured a $T_{\mathrm{opt}}$ of only $12{ }^{\circ} \mathrm{C}$ after $36 \mathrm{~h}$ of incubation. Such a low $T_{\mathrm{opt}}$ in combination with a high relative respiration rate of $50 \%$ at in situ temperature suggests the presence of a well-adapted psychrophilic community. A similar low $T_{\mathrm{opt}}$ of $12.5^{\circ} \mathrm{C}$ for sulfate reduction was observed in sediment from Antarctica in the Weddell Sea (Isaksen and Jørgensen, 1996). The authors incubated sediment for 8 days and reasoned that this allowed the growth of sulfate-reducing bacteria. The observed $T_{\text {opt }}$ therefore likely reflected the growth rate optimum of a predominantly psychrophilic community (Isaksen and Jørgensen, 1996).

The incubations in our studies were short (max. $36 \mathrm{~h}$ ) and the SRR therefore reflect the short-term enzymatic capabilities of the in situ sulfate-reducing community. Prolonged incubations in similar experiments have shown that the temperature optimum decreases over time (Brüchert et al., 2001; Finke and Jørgensen, 2008). It is apparent that sulfate-reducing microorganisms from these cold sediments maintain high activity at the highest temperatures only for a limited time. Instead, relative respiration rates of an adapted community remain constant for a longer time even when sediment is exposed to higher temperature (Robador et al., 2009). The temperature-sulfate reduction rate diagrams shown in our study should therefore not be misunderstood as indicators of the true $T_{\mathrm{opt}}$ of the sulfate-reducing community, but in combination with $T_{\min }, T_{\max }$ and relative respiration rates should be regarded as temperature characteristics of the existing populations. These community temperature characteristics allow comparisons with populations in other sediments and, along with additional verifying methods, temperature response profiles may be indicative of the origins of these populations and their temperature characteristics.

\subsection{SRR in shelf and slope sediments fall into three temperature groups}

In the South Atlantic and Arctic sediments, the multiple parameters of the temperature-SRR diagrams imply the presence of mesophilic, psychrotolerant, and psychrophilic SRBs. The high percentage of SRR at the in situ temperature and the low $T_{\mathrm{opt}}$ measured for the Argentinian slope sediment from $3400 \mathrm{~m}$ depth indicate the predominance of a psychrotolerant and psychrophilic community (Fig. 1e). In other sediments, these distinct characteristics are more obscured and suggest the existence of mixed populations of mesophilic and/or psychrotolerant SRBs.

In the Namibian shelf and slope sediments, the rates at in situ temperature were low and less than $10 \%$ of the rates at $T_{\text {opt }}$ (Table 3 ), suggesting a poorly adapted sulfate-reducing community. By contrast, the $E_{\mathrm{a}}$ values of 38 and $55 \mathrm{~kJ} \mathrm{~mol}^{-1}$ suggested that SRB were well adapted to the ambient temperature. The corresponding $Q_{10}$ values for SRR were around 2, which is typical for experimental studies from many marine environments (Kirchman et al., 2009). These low $Q_{10}$ values were found repeatedly for metabolic processes in Arctic and Antarctic sediments and imply a microbial community well adapted to ambient temperature. $E_{\mathrm{a}}$ values reported for 
permanently cold sediments vary in the range of $25-31 \mathrm{~kJ}$ $\mathrm{mol}^{-1}$, depending on whether the community is more psychrotolerant or psychrophilic. Our $E_{\mathrm{a}}$ values were similar to those measured for sulfate reduction, denitrification and anammox in Arctic sediments from eastern Greenland and western Svalbard fjords (Fig. 2, Table 3) (Rysgaard et al., 1998; Gihring et al., 2010).

In the three Arctic deep-fjord sediments, the sulfatereducing communities also had some inconsistent temperature characteristics: Although the relative respiration rates were all close to $20 \%$, the $T_{\text {opt }}$ varied between 18 and $27^{\circ} \mathrm{C}$. The relative respiration rates classify the temperature response as psychrophilic and psychrotolerant, but the combination of a relative respiration rate of $20 \%$ and a high $T_{\mathrm{opt}}$ of $27^{\circ} \mathrm{C}$ suggests a temperature response of SRBs from the intertidal sediment that is psychrotolerant to mesophilic.

The temperature response characteristics of some South Atlantic slope sediments also differed in terms of $T_{\mathrm{opt}}$ and broadness of the curves. $T_{\mathrm{opt}}$ and low relative SRR of Argentinean $(4327 \mathrm{~m})$ and Namibian slope $(2000 \mathrm{~m})$ sediment suggest the presence of psychrotolerant bacteria, but also the additional presence of mesophilic populations. We hypothesize that these differences can be attributed to the strength of the influx of a seed population from warmer environments - in this case warmer shelf locations. This could explain the mesophilic signature of microorganisms derived from the shelf by sediment transport (Fig. 1c, d, f).

\subsection{Sediment transport effects on experimentally- determined temperature-activity relationships}

Passive movement of microorganisms with currents and water masses is an important mechanism of marine microbial dispersal (Martiny et al., 2006). Benthic bacteria in surface sediments can be suspended to the water column due to physical disturbance by near-bed currents and macroorganisms (Queric and Soltwedel, 2007; Schauer et al., 2010). Sediment transport and hydrographic conditions could explain the $9{ }^{\circ} \mathrm{C}$ difference in $T_{\text {opt }}$ in three nearby deep-fjord Arctic sediments. Smeerenburgfjord, at the northwestern tip of Spitzbergen, is a narrow protected coastal strait open to the Fram Strait in the west and towards the Arctic Ocean in the north. It is strongly affected by warm, Atlantic-derived water that is constantly supplied from the south and flushed to the north (Caroll et al., 2011). This process might affect benthic conditions and contribute to the import of less-adapted microorganisms with higher $T_{\mathrm{opt}}$ or even displace well-adapted microorganisms. The other two sites were located deep within the Kongsfjorden and Krossfjorden. Kongsfjorden is an open fjord and creates, along with Krossfjorden, a system that merges before opening into Fram Strait. Both coastal and Atlantic water flows into it and there is significant freshwater and sediment influx in the summer from melting snow, precipitation, glacial calving and runoff (Cottier et al., 2005). This material may also transport an allochthonous micro- bial community with higher temperature characteristics that leaves an imprint in the form of different $T_{\text {opt }}$.

In the South Atlantic slope sediments, resuspension and dispersion of suboptimally adapted microorganisms may inherit a mesophilic signature of a shelf SRB community to these deep-sea sediments. Organic matter from the coastal Benguela upwelling system on the Namibia shelf undergoes continuous suspension and redeposition leading to a net downslope transport. The shelf material accumulates in depocenters at $1000-1500 \mathrm{~m}$ water depth, where the sediment is rich in organic matter (Inthorn et al., 2005, 2006). The slope sediments off Uruguay and Argentina are also characterized by dynamic depositional conditions (Riedinger et al., 2005). Attempts have been made to resolve the contribution of shelfderived material through benthic nepheloid layer transport by means of ${ }^{230} \mathrm{Th}$ flux measurements and ${ }^{14} \mathrm{C}$ radiocarbon analyses for the Namibian and Argentinian slope (Mollenhauer et al., 2006, 2008). The interpretations presented in these studies emphasize the temporal and spatial variability in lateral export intensity. Such variability likely affects the proportional mixtures of microorganisms with different temperature adaptations.

We suggest that the downslope transport of sediment material from the warmer continental shelf to the permanently cold continental slope may seed deep-water sediments with mesophilic organisms. Anaerobic sulfate-reducing bacteria face the problem of toxic exposure to oxygenated water during transport. However, a number of SRB have been shown to develop molecular strategies to remove oxygen or to use oxygen temporarily for respiration to reduce its toxicity (Cypionka, 2000; Dolla et al., 2006). In addition, mass transport often occurs in the form of aggregates, whose insides can be anoxic (Ploug et al., 1997).

Mesophilic and psychrotolerant SRB deposited on cold slope sediments would appear less competitive compared to their autochthonous psychrophilic counterparts (Knoblauch and Jørgensen, 1999; Robador et al., 2009). For long-term survival and success, rate of growth and growth yield are true measures of microbial adaptation to environmental temperatures. Environmental conditions in organic matter-limited deep-sea sediment impose nutritional constraints that can impede microbial growth. It is conceivable that psychrotolerant bacteria transported downslope have adaptive mechanisms to maximize and maintain a high growth yield at low temperature (Bakermans and Nealson, 2004), but it is not clear how allochthonous, mesophilic SRB derived from the shelf may proliferate when relocated to greater depths. It is noteworthy, however, that in laboratory studies both psychrophilic and mesophilic sulfate-reducing bacteria have shown comparable growth rates when grown on lactate (Knoblauch and Jørgensen 1999, Sass et al., 1998), suggesting that proliferation of mesophiles in permanently cold environments is conceivable. The hypothesis that allochthonous mesophilic SRB are transported from the shelf and remain viable in permanently cold sediment is also supported by sulfate reduction 
rates measured in intertidal temperate sediment that showed a characteristic mesophilic temperature response even when the sediment was stored for two years at $0^{\circ} \mathrm{C}$, not changing the temperature response very much over this period of time (Robador et al., 2009). Clearly, despite the low ambient temperatures, the mesophilic sulfate-reducing community proliferated (Robador et al., 2009).

\section{Conclusions}

$T_{\min }, T_{\max }$, and $T_{\mathrm{opt}}$ for SRR in various continental shelf and slope sediments from the Atlantic and Arctic Oceans indicate the coexistence of different thermal groups of SRB. This observation has implications for predicting the likely outcome of long-term temperature changes of marine sediments in Arctic shelf and deep-sea habitats. The seeding of permanently cold deep-sea habitats with mesophilic microorganisms must affect growth rates of the bacterial community at changed bottom water temperatures and can thus potentially affect the efficiency of organic carbon mineralization rates. The existing evidence from this study and from previous comparisons of carbon mineralization in permanently cold and temperate habitats points to the availability of reactive organic matter as the overriding limiting factor for longterm carbon mineralization in marine sediment (Kostka et al., 1998). Incubation experiments of SRR over two years (Robador et al., 2009) and recent experimental studies from lake sediment (Gudasz et al., 2010) suggest, however, a more prominent role of temperature limitation. These different observations can be reconciled if one considers that an apparent temperature limitation effect may be temporary and is alleviated by community replacement with better temperature adaptations. The regional comparison indicates that over longer time scales, bacteria with the best physiological adaptation to exploit the available conserved energy in the respective environment will likely prevail. In the future it will be important to explore at what time scale such a community change to the best-adapted community occurs.

Acknowledgements. This work was supported by DFG grant BR2174/1-2 to Volker Brüchert in the DFG priority program AQUASHIFT and the Max-Planck Society. We are grateful to Natascha Riedinger, Gail L. Arnold, Antje Voßmeyer, Sabine Kasten, Susann Henkel and Mike Formolo for help with collecting the samples during Meteor cruises M76 and M78. JES would like to acknowledge Alberto Robador for instruction in the use of the temperature gradient block and Ben Brunner for extensive discussions. The DFG and the MARUM Research Center/Cluster of Excellence "The Ocean in the Earth System" at the University of Bremen are acknowledged for funding and cruise organization. We also thank the crews and captain of RV FARM for well-organized cruises to the Svalbard fjords, and the Koldevey Station of the Alfred Wegener Institute for providing laboratory space in Ny Ålesund, Svalbard.
The service charges for this open access publication have been covered by the Max Planck Society.

Edited by: G. Herndl

\section{References}

Aono, E., Baba, T., Ara, T., Nishi, T., Nakamichi, T., Inamoto, E., Toyonaga, H, Hasegawa, M., Takai, Y., Okumura, Y., Baba, M., Tomita, M., Kato, C., Oshima, T., Nakasone, K., and Mori, H.: Complete genome sequence and comparative analysis of Shewanella violacea, a psychrophilic and piezophilic bacterium from deep sea floor sediments, Mol. Biosyst., 6, 1216-1226, 2010.

Arrhenius, S.: Immunochemie. Ergebnisse der Physiologie, Biologischen Chemie und experimentellen Pharmakologie, 7, 480 551, 1908 (in German).

Bakermans, C. and Nealson, K. H.: Relationship of critical temperature to macromolecular synthesis and growth yield in Psychrobacter cryopegella, J. Bacteriol., 186, 2340-2345, 2004.

Battley, E. H.: A thermal gradient block for determination of temperature relationships in microorganisms, Antonie van Leeuwenhoek, 30, 81-96, 1964.

Behrenfeld, M. J. and Falkowski, P. G.: A consumers guide to phytoplankton primary productivity models, Limnol. Oceanogr., 42, 1479-1491, 1997.

Brüchert, V., Knoblauch, C., and Jørgensen, B. B.: Controls on stable sulfur isotope fractionation during bacterial sulfate reduction in Arctic sediments, Geochim. Cosmochim. Acta, 65, 763-776, 2001.

Brüchert, V., Jørgensen, B. B., Neumann, K., Riechmann, D., Schlösser, M., and Schulz, H.: Regulation of bacterial sulfate reduction and hydrogen sulfide fluxes in the central Namibian coastal upwelling zone, Geochim. Cosmochim. Ac., 67, 45054518, 2003.

Brüchert, V., Bronwen, C., and Peard, R. K.: Hydrogen sulphide and methane emissions on the central Namibian shelf, Prog. Oceanogr., 83, 169-179, 2009.

Bryant, M. P.: Commentary on hungate technique for culture of anaerobic bacteria, The Am. J. Clin. Nutr., 25, 1324-1328, 1972.

Carr, M.-E.: Estimation of potential productivity in Eastern Boundary Currents using remote sensing, Deep-Sea Res. II, 49, 59-80, 2002.

Carmack, E., Barber, D., Christensen, J., Macdonald, R., Rudels, B., and Sakshaug, E.: Climate variability and physical forcing of the food webs and carbon budget on panarctic shelves, Prog. Oceanogr., 71, 145-181, 2006.

Caroll, M. L., Ambrose Jr., W. G., Levin, B. S., Locke, V. W., Henkes, G. A., Hop, H., and Renaud, P. E.: Pan-Svalbard growth rate variability and environmental regulation in the Arctic bivalve Serripes groenlandicus, J. Mar. Syst., 88, 239-251, 2011.

Casanueva, A., Tuffin, M., Cary, C., and Cowan, D. A.: Molecular adaptations to psychrophily: the impact of omic technologies, Trends Microbiol., 18, 374-381, 2010.

Chen, X.-L., Zhang, Y.-Z., Gao, P.-J., and Luan, X.-W. : Two different proteases produced by a deep-sea psychrotrophic bacterial strain, Pseudoaltermonas SM9913, Mar. Biol., 143, 989-993, 2003. 
Cottier, F., Tverberg, V., Inall, M., Svendsen, H., Nilsen, F., and Griffiths, C.: Water mass modification in an Arctic fjord through cross-shelf exchange: the seasonal hydrography of Kongsfjorden, Svalbard, J. Geophys. Res., 110, 18 pp., doi:10.1029/2004JC002757, 2005.

Cypionka, H.: Oxygen respiration by Desulfovibrio species, Annu. Rev. Microbiol., 54, 827-848, 2000.

D'Hondt, S., Rutherford, S., and Spivack, A. J.: Metabolic activity of subsurface life in deep-sea sediments, Science, 295, 20672070, 2002.

Dolla, A., Fournier, M., and Dermoun, Z.: Oxygen defense in sulfate-reducing bacteria, J. Biotechnol., 126, 87-100, 2006.

Feller, G.: Life at low temperatures: is disorder the driving force?, Extremophiles, 11, 2011-2016, 2007.

Ferdelman, T. G., Fossing, H., Neumann, K., and Schulz, D. H.: Sulfate reduction in surface sediments of the southeast Atlantic continental margin between $15^{\circ} 38^{\prime} \mathrm{S}$ and $27^{\circ} 57^{\prime} \mathrm{S}$ (Angola and Namibia), Limnol. Oceanogr., 44, 650-661, 1999.

Finke, N. and Jørgensen, B. B.: Response of fermentation and sulfate reduction to experimental temperature changes in temperate and Arctic marine sediments, ISME J., 2, 815-829, 2008.

Finster, K. and Bak, F.: Complete Oxidation of Propionate, Valerate, Succinate, and Other Organic Compounds by Newly Isolated Types of Marine, Anaerobic, Mesophilic, Gram-Negative, Sulfur-Reducing Eubacteria, App. Environ. Microbiol., 59, 1452-1460, 1993.

Fossing, H.: ${ }^{35}$ S-Radiolabeling to probe biogeochemical cycling of Sulfur, in: Geochemical Transformations of Sedimentary Sulfur: American Chemical Society, 348-364, 1995.

Fossing, H. and Jørgensen, B. B.: Measurement of bacterial sulfate reduction in sediments. Evaluation of a single-step chromium reduction method, Biogeochemistry, 8, 205-222, 1989.

Gihring, T., Lavik, G., Kuypers, M., and Kostka, J. E.: Direct determination of nitrogen cycling rates and pathways in Arctic fjord sediments (Svalbard, Norway), Limnol. Oceanogr., 55, 740-752, 2010.

Gudasz, C., Bastviken, D., Steger, K., Premke, K., Sobek, S., and Tranvik L. J.: Temperature-controlled organic carbon mineralization in lake sediments, Nature, 466, 478-481, 2010.

Hansen, C., Zabel, M., Pfeifer, K., Schwenk, T., Kasten, S., Riedinger, N., Schulz, H. D., and Boetius, A.: Control of sulfate pore-water profiles by sedimentary events and the significance of anaerobic oxidation of methane for burial of sulfur in marine sediments, Geochim. Cosmochim. Ac., 67, 2631-2647, 2003.

Hubert, C., Loy, A., Nickel, M., Arnosti, C., Baranyi, C., Brüchert, V., Ferdelman, T., Finster, K., Christensen, F. M., de Rezende, J. R., Vandieken, V., and Jørgensen, B. B.: A constant flux of diverse thermophilic bacteria into the cold Arctic seabed, Science, 325, 1541-1544, 2009.

Inthorn, M., Wagner, T., Scheeder, G., and Zabel, M.: Lateral transport controls distribution, quality, and burial of organic matter along continental slopes in high-productive areas, Geology, 34, 205-208, 2005.

Inthorn, M., Mohrholz, V., and Zabel, M.: Nephloid layer distribution in the Benguela upwelling area offshore Namibia, Deep-Sea Res., 53, 1423-1438, 2006.

Isaksen, M. F., Bak, F., and Jørgensen, B. B.: Thermophilic sulfatereducing bacteria in cold marine sediment, FEMS Microbiology Ecol., 14, 1-8, 1994.
Isaksen, M. F. and Jørgensen, B. B.: Adaptation of psychrophilic and psychrotrophic sulfate-reducing bacteria to permanently cold marine environments, App. Environ. Microbiol., 62, 408-414, 1996.

Jørgensen, B. B.: A comparison of methods for the quantification of bacterial sulfate reduction in coastal marine sediments, Geomicrobiol. J., 1, 11-27, 1978.

Kallmeyer, J., Ferdelman, T. G., Weber, A., Fossing, H., and Jørgensen, B. B.: A cold chromium distillation procedure for radiolabeled sulfide applied to sulfate reduction measurements, Limnol. Oceanogr- Meth., 2, 171-180, 2004.

Kasten, S. and Jørgensen, B. B.: Sulfate reduction in marine sediments, in: Marine Geochemistry Springer Berlin Heidelberg, 271-309, 2006

Kirchman, D. L., Moran, X. A. G., and Ducklow, H.: Microbial growth in polar oceans - role of temperature and potential impact of climate change, Nat. Rev. Microbiol., 7, 451-459, 2009.

Knoblauch, C. and Jørgensen, B. B.: Effect of temperature on sulphate reduction, growth rate and growth yield in five psychrophilic sulphate reducing bacteria from Arctic sediments, Environ. Microbiol., 1, 547-467, 1999.

Kostka, J. E., Thamdrup, B., Glud, N. R., and Canfield, D. E.: Rates and pathways of carbon oxidation in permanently cold Arctic sediments, Mar. Ecol.-Prog. Ser., 180, 7-21, 1999.

Krastel, S. and Wefer, G.: Report and preliminary results of RV METEOR Cruise M78/3. Sediment transport off Uruguay and Argentina: from the shelf to the deep sea; 19 May 200906 July 2009, Montevideo (Uruguay) - Montevideo (Uruguay), available at: http://oceanrep.geomar.de/id/eprint/14226, 2009.

Lass, H. U. and Mohrholz, V.: On the fluctuations and vertical structure of the shelf circulation off Walvis Bay, Namibia, Cont. Shelf Res., 25, 1473-1497, 2005.

Lee, T., Hyun, J., Mok, J. S., and Kim, D.: Organic carbon accumulation and sulfate reduction rates in slope and basin sediments of the Ulleung Basin, East/Japan Sea, Geo-Mar Lett., 28, 153-159, 2008.

Leloup, J., Loy, A., Knab, N. J., Borowski, C., Wagner, M., and Jørgensen, B. B.: Diversity and abundance of sulfate-reducing microorganisms in the sulfate and methane zones of a marine sediment, Black Sea, Environ. Microbiol., 9, 131-142, 2007.

Levitus, S. and Boyer, T.: World Ocean Atlas, Volume 4: Temperature, Washington D.C., US Department of Commerce, 1994.

Margesin, R. and Miteva, V.: Diversity and ecology of psychrophilic microorganisms, Res. Microbiol., 162, 1-16, 2011.

Martiny, J. B. H., Bohannan, B. J. M., Brown, J. H., Colwell, R. K., Fuhrman, J. A., and Green, J. L.: Microbial biogeography: putting microorganisms on the map, Nat. Rev. Microbiol., 4, 102-112, 2006.

Meyers, P. A.: Preservation of elemental and isotopic source identification of sedimentary organic matter, Chem. Geol., 114, 289302, 1994.

Morita, R. Y.: Psychrophilic bacteria, Microbiol, Mol. Biol. Rev., 39, 144-167, 1975.

Mollenhauer, G., McManus, J. F., Benthien, A., Muller, P. J., and Eglinton, T. I.: Rapid lateral particle transport in the Argentine Basin: molecular 14C and 230Thxs evidence, Deep Sea Res. Part I: Oceanogr. Res. Pap., 53, 1224-1243, 2006.

Mollenhauer, G., Inthorn, M., Vogt, T., Zabel, M., and Sinninhe Damste, J. S., Eglinton, T. I.: Aging of marine 
organic matter during cross-shelf lateral transport in the Benguela upwelling system revealed by compound-specific radiocarbon dating, Geochem. Geophy. Geosy., 8, Q09004, doi:10.1029/2007GC001603, 2008.

Nordli, Ø.: Temperature variations at Svalbard during the last century, Nordicspace, 13, 6-7, 2005.

Ortega, L. and Martinez, A.: Multiannual and seasonal variability of water Masses and fronts over the Uruguayan shelf, J. Coastal Res., 23, 618-629, 2007.

Ploug, H., Kühl, M., Bucholz, B., and Jorgensen, B. B.: Anoxic aggregates - an ephemeral phenomenon in the pelagic environment, Aquat. Microb. Ecol., 13, 285-294, 1997.

Queric, N. V. and Soltwedel, T.: Impact of small-scale biogenic sediment structures on bacterial distribution and activity in Arctic deep-sea sediments, Mar. Ecol.-Evol. Persp., 28, 66-74, 2007.

Riedinger, N., Pfeifer, K., Kasten, S., Lukina, F. J., Garming, V. C., and Hensen, C.: Diagenetic alteration of magnetic signals by anaerobic oxidation of methane related to a change in sedimentation rate, Geochim. Cosmochim. Ac., 69, 4117-4126, 2005.

Robador, A., Brüchert, V., and Jørgensen, B. B.: The impact of temperature change on the activity and community composition of sulfate-reducing bacteria in Arctic versus temperate marine sediments, Environ. Microbiol., 11, 1692-1703, 2009.

Robador A., Brüchert, V., Steen, A. and Arnosti, C.: Temperature induced decoupling of enzymatic hydrolysis and carbon remineralization in long-term incubations of Arctic and temperate sediments, Geochim. Cosmochim. Ac., 74, 2316-2326, 2010.

Rysgaard, S., Thamdrup, B., Risgaard-Petersen, N., Fossing, H., Berg, P., Bondo, P. B., and Dalsgaard, T.: Seasonal carbon and nutrient mineralization in a high-Arctic coastal marine sediment, Young Sound, Northeast Greenland, Mar. Ecolog. Prog. Ser., 175, 261-276, 1998.

Rüger, H. J.: Benthic studies of the Northwest African upwelling region: psychrophilic and psychrotrophic bacterial communities from areas with different upwelling intensities, Mar. Ecol.-Prog. Ser., 57, 45-52, 1989.

Rüger, H. J. and Tan, L. T.: Community structures of cold and lownutrient adapted heterotrophic sediment bacteria from the deep eastern tropical Atlantic, Mar. Ecol.-Prog. Ser., 84, 83-93, 1992.
Sagemann, J., Jørgensen, B. B., and Greef, O.: Temperature dependence and rates of sulfate reduction in cold sediments of Svalbard, Arctic Ocean, Geomicrobiol. J., 15, 85-100, 1998.

Sahm, K., Knoblauch, C., and Amann, R.: Phylogenetic affiliation and quantification of psychrophilic sulfate-reducing isolates in marine Arctic Sediments, App. Environ. Microbiol., 65, 39763981, 1999.

Sakshaug, E.: Primary and secondary production in the Arctic Seas, in: The organic carbon cycle in the Arctic Ocean, edited by: Stein, R. and Macdonald, R. W., 57-81, 2004.

Sass, H., Berchtold, M., Branke, J., König, H., Cypionka, H., and Babenzien, H. D.: Psychrotolerant sulfate-reducing bacteria from an oxic freshwater sediment, description of Desulfovibrio cuneatus sp. nov. and Desulfovibrio litoralis sp. nov., Syst. Appl. Microbiol., 21, 212-219, 1998.

Sawicka, J. E., Robador, A., Hubert, C., Jørgensen, B. B., and Brüchert, V.: Effects of freeze-thaw cycles on anaerobic microbial processes in an Arctic intertidal mud flat, ISME J., 4, 585594, 2010.

Schauer, R., Bienhold, C., Ramette, A., and Harder, J.: Bacterial diversity and biogeography in deep-sea surface sediments of the South Atlantic Ocean, ISME J., 4, 159-170, 2010.

Siedler, G.: in: The South Atlantic, present and past circulation, edited by: Wefer, G., Berger, W. H., Siedler, G., and Webb, D. J., 83-104, Springer Verlag, or see World Ocean Data set at: http://www.nodc.noaa.gov/OC5/SELECT/dbsearch/ dbsearch.html), 1996.

Ting, L., Williams, T. J., Cowley, M. J., Lauro, F. M., Guilhaus, M., Raftery, M. J., and Cavicchioli, R.: Cold adaptation in the marine bacterium, Sphingopyxis alaskensis, assessed using quantitative proteomics, Environ. Microbiol., 12, 2658-2676, 2011.

Widdel, F. and Bak, F.: Gram-negative mesophilic sulfate-reducing bacteria, in: The Prokaryotes 2nd Edn., edited by: Balows, A., Trüper, H. G., Dworking, M., Harder, W., and Schleifer, K.-H., Springer, Berlin, Heidelberg and New York, 1992.

Zabel, M. and Ferdelman, T. G.: Short cruise report Meteor cruise M76-1, available at: http://www.ifm.zmaw.de/fileadmin/ files/leitstelle/meteor/M76/M76-1-SCR.pdf (last access: $22 \mathrm{Au}$ gust 2012), 2008. 